\title{
The Use of Mineral Nutrients for Biomass Production by Young Birch Stands and Stands Vitality in Different Forest Growing Conditions
}

\author{
Mudrite Daugaviete ${ }^{1}$, Ausma Marija Korica ${ }^{2}$, Ingars Silins ${ }^{3}$, Arvids Barsevskis ${ }^{4}$, Andis Bardulis ${ }^{1}$, Arta Bardule ${ }^{1}$, \\ Kaspars Spalvis ${ }^{2}$ and Maris Daugavietis ${ }^{2}$ \\ 1. Department of Forest Regeneration and Establishment, Latvian State Forest Research Institute "Silava”, Salaspils LV-2169, Latvia \\ 2. Department of Forest Products Processing, Latvian State Forest Research Institute "Silava", Salaspils LV-2169, Latvia \\ 3. Department of Entomology, Latvian State Forest Research Institute "Silava", Salaspils LV-2169, Latvia \\ 4. Rector of Daugavpils University, 13, Vienības Street, Daugavpils LV-5401, Latvia
}

\begin{abstract}
The data of field studies about mineral nutrient content in the biomass components of young birch stands (9-15 years old) in different forest growing conditions and soil types have been analyzed. In forest growing conditions on fertile soils (ASG, TSC and SP) the total amount of biomass produced by young birch stands divides into fractions as follows: stem wood $51.8 \%-59.5 \%$; branch wood 9.8\%-12.4\%; foliage 5.7\%-6.8\%; stump wood and roots $25 \%-30 \%$. In forest types on lean soils (TP) the same indices are $32.3 \%-41.8 \%, 18.2 \%-24.2 \%, 13.2 \%-16.1 \%$ and $26.8 \%-27.4 \%$, respectively. The stand performance closely correlates with the basic nutrient (P, N, K, C and Mg) availability in forest soils. In lean typicpodzol soils (TP) the content of mineral nutrients is no higher than $20 \%-48 \%$ of that in more fertile soils (ASG, TSC and SP). In young birch stands the take-up of mineral nutrients from $0-40 \mathrm{~cm}$ soil layer for developing the above-ground biomass makes a fairly small proportion of the total: up to $4.8 \%-6.2 \%$ for $\mathrm{P} ; 4.9 \%-12.2 \%$ for $\mathrm{N} ; 1.1 \%-4.1 \%$ for $\mathrm{K} ; 11.6 \%$ for $\mathrm{Ca} ; 0.8 \%-7.7 \%$ for $\mathrm{Mg}$; in leaner soils the same indices are $\mathrm{P} 0.1 \%-0.4 \%, \mathrm{~N} 1 \%-1.5 \%, \mathrm{~K}$ $0.2 \%-0.6 \%, \mathrm{Ca} 0.1 \%-0.9 \%, \mathrm{Mg} 0.1 \%-0.8 \%$, respectively. The analyses of pest damages in young birch stands confirm a hypothesis that the degree of pest damage depends on the stand vitality as described by the site index.
\end{abstract}

Key words: Betula pendula Roth, forest growing conditions, soil types, mineral nutrients, biomass.

\section{Introduction}

With the proportion of silver birch (Betula pendula Roth) in the forest stock increasing, at present accounting for $27.95 \%$ (883,600 ha) of the Latvia's forest area with the stock volume 153 million $\mathrm{m}^{3}$ ( $24.3 \%$ of the total), birch stands strongly affect the forest ecosystem as a whole [1]. That is why the authors need to know nutritional requirements for birch and mineral nutrient cycling in birch forests, which may significantly impact the sustainability of forest biocenosis.

Ample research on the organics turnover and

Corresponding author: Mudrite Daugaviete, doctor, senior researcher field: forest regeneration. E-mail: mudrite.daugaviete@silava.lv. mineral nutrient cycling in forest ecosystems is done by the British researcher J. D. Ovington [2] with the following conclusions: woodlands as a producer of both commercial timber (economic aspect) and all types of organic matter (biological aspect) should be considered the most unique ecosystems, functioning on an advanced level. In essence, forest is a self-regulatory system, which intensively regenerates organic matter. As an example mentioned the highly productive beech stand in New Zealand, where the annual consumption of $\mathrm{K}, \mathrm{Ca}, \mathrm{Mn}, \mathrm{P}$ and $\mathrm{N}$ is accordingly $34,84,12,3$ and $40 \mathrm{~kg} \cdot \mathrm{ha}^{-1}$, with the amount of the same elements produced annually by forest litter and residues 30, 74, 2, 6 and $37 \mathrm{~kg} \cdot \mathrm{ha}^{-1}$, correspondingly [2]. 
It follows, that at present the major issue is to identify the actual causes for the rise of stable and highly productive forest stands: soil fertility, mineral nutrient cycling, hydrological regime, genetic factors, climate changes, etc. [3-13].

Russian scientists have worked out a model SOMM for simulating such processes in forest ecosystems as soil organics mineralization, humification, and nitrogen turnover. It allows modelling nutrient cycling over a vast geographic area between the tundra and the tropical rain forests following the nitrogen content in forest litter, the air temperature and precipitation [14].

In order to reveal the course of mineral nutrient cycling in forest ecosystems, the researchers have studied the performance in the European boreal forest zone of Scots pine (Pinussylvestris L.), Norway spruce (Piceaabies (L.) Karst.) and silver birch (Betula pendula Roth), developing a single plant ecosystem model EFIMOD, which was improved within the COST Project FP0804-Forest Management Decision Support Systems (FORSYS) $[15,16]$. The EFIMOD simulates the biological cycle for each tree, calculating the total amount of biomass produced by tree foliage, roots and litter [17].

However, it should be remembered that the above models require corrections to account for such factors, at present affecting plant growth, as the accumulation of carbon dioxide gas in the atmosphere, which provokes global warming and significantly affects the nutritional regime of plants, resulting not only in mineral deficiency, but also overabundance of some mineral nutrients, thus disrupting the nutrient balance, which affects the ecosystem functioning [9-11, 18].

In some European countries, including Latvia, birch severely suffers from both unsuitable soil conditions and a variety of pests, which feed on birch leaves, taking away water that considerably reduces photosynthesis and stunts tree growth [19-21]. It is mainly primary pests, which feed on birch leaves and reduce trees resistance against adverse conditions [22]. Subdued trees emit in the atmosphere phytoncids, which serve as a warning to other trees to increase the synthesis of tannins in order to survive in unfavourable conditions [23]. The secondary pests, mainly the Scolytidae, guided by the presence of tannins in the atmosphere, find the weakened trees and attack their stems, branches, bark and roots, quite often killing the infected tree [24, 25]. It is known that in situations, where over $55 \%$ of birch foliage is pest-damaged, the risk of secondary pest multiplication substantially increases [26].

In Latvia, the research on mineral nutrient cycling in birch stands is so far scanty [27-29]. Between 2009 and 2012, the Latvian State Forestry Research Institute Silava carried out a project on mineral nutrient cycling in birch stands, funded by the Latvian Academy of Sciences [30]. In 2012-2013, the related research work was continued within the ERDF Project "Technologies for establishing and managing tree plantations for producing birch wood" (No 2010/0319/2DP/2.1.1.1.0/10/APIA/VIAA/136).

Research objectives: establishing the content of individual mineral nutrients in the tree above-ground and root biomass, depending on mineral nutrient availability in forest soils and investigating the vitality of young stands of birch.

\section{Material and Methods}

During the 2012 and 2013 vegetation season mineral nutrient cycling was studied in five young birch stands in different regions of the country and in different forest growing conditions, involving both rich agricultural soils and lean sandy ones: alluvial sod-gley soil (ASG) - forest type Aegopodiosa; typic sod-calcareous soil on heavy clay (TSC)-forest type Hylocomiosa; sod-podzolic soil on sandy clay (SP)—forest type Oxalidosa; typicpodzol sandy soil (TP) - forest types Cladinoso-callunosa $\left(\mathrm{TP}_{1}\right)$ and Myrtillosa $\left(\mathrm{TP}_{2}\right)$. The description of birch stands used for the experiment is given in Table 1.

To collect the field data for analysing tree above-ground biomass, four circular sample plots 


\section{Stands Vitality in Different Forest Growing Conditions}

(size $500 \mathrm{~m}^{2}$ ) were set up in each experimental site, with the following measurements made: tree height with the precision $\pm 0.02 \mathrm{~m}$, using a measuring bar, as well as the Vertex III measuring gauge (precision $\pm 0.10 \mathrm{~m})$, the $\mathrm{DBH}\left(\mathrm{D}_{1,3}\right)$ - by using the Mantax Precision diameter gauge (precision $\pm 0.01 \mathrm{~cm}$ ).

In each plot the above-ground biomass samples (foliage, wood unbarked, branch wood unbarked) were taken from five sample trees, whose dimensions with an accuracy of $\pm 0.5 \mathrm{~cm}$ matched those of the stand's mean tree.

To determine the amount of root mass, in each sample plot 2-3 sample trees were stubbed up, weighing the fractions of stump wood and roots. To get the weight of absolute dry mass, samples of birch biomass fractions (foliage, wood unbarked, branch wood unbarked, stump wood and roots) were dried at the temperature $105{ }^{\circ} \mathrm{C}$ into a uniform mass, which was weighed with a precision $\pm 0.02 \mathrm{~g}$.

Soil samples in each sample plot were taken in the tree root zone at the depth of $0-40 \mathrm{~cm}(0-10 ; 10-20$;
20-30 and 30-40 cm) in five replications, making a mean sample for each soil layer [32]. The chemical analyses of soil (Tables 2 and 3) and individual birch biomass components (3) were done at the Latvian Environment, Geology and Meteorology Centre after the LVS ISO standards.

For each sample plot calculated is the stock volume [33], mean tree volume, the amount of each tree biomass fraction (foliage, wood unbarked, branch wood unbarked, stump wood and roots), and also the amount of freshly cut and absolutely dry biomass.

The mean diameter for birch stands of the height above $9 \mathrm{~m}$ is calculated as the mean weighted value for the respective basal area class, using the inventory data:

$$
g_{v}=\frac{\sum g_{j}}{N}
$$

Where,

$g_{v}$-basal area of the stand's mean tree, $\mathrm{m}^{2}$;

$g_{j}$ - tree basal area, $\mathrm{m}^{2}$.

$$
d_{v}=\sqrt{\frac{4 \cdot g_{v}}{\pi}}
$$

Table 1 Description of experimental sites.

\begin{tabular}{llllllll}
\hline $\begin{array}{l}\text { Site location, } \\
\text { Lat/Lon (DD) }\end{array}$ & Soil type & Forest type* & Site index & Stand age & Mean DBH, cm & Mean height, m & Stand origin \\
\hline $56.54944 / 24.325$ & ASG & Aegopodiosa & Ib & 15 & 10.3 & 12.5 & AAL \\
$57.05305 / 22.73916$ & SP & Oxalidosa & I & 10 & 8.6 & 7.4 & AAL \\
$56.91972 / 22.69166$ & TSC & Hylocomiosa & II & 15 & 9.0 & 10.0 & AAL \\
$57.13856 / 24.36526$ & $\mathrm{TP}_{1}$ & Cladinoso-callunosa & III & 9 & 1.2 & 2.5 & NRS \\
$56.91355 / 24.28131$ & $\mathrm{TP}_{2}$ & Myrtillosa & III & 10 & 2.5 & 3.9 & NRS \\
\hline
\end{tabular}

*AAL-afforested agricultural land; NRS—naturally regenerated stand; ASG-alluvial sod-gley soil; SP-sod-podzolic soil; TSC - typic sod-calcareous soil on heavy clay; TP_typicpodzol on sandy soil [31].

\begin{tabular}{|c|c|c|c|c|c|}
\hline \multirow[b]{2}{*}{ Mineral substance } & \multicolumn{5}{|c|}{ Forest type/soil type } \\
\hline & Aegopodiosa/ASG & Oxalidosa/SP & Hylocomiosa/TSC & $\begin{array}{l}\text { Cladinoso-cal- } \\
\text { lunosa } / \mathrm{TP}_{1}\end{array}$ & Myrtillosa $/ \mathrm{TP}_{2}$ \\
\hline $\begin{array}{l}\text { Proportion of organics in dry matter } \\
\text { (\%) }\end{array}$ & $2.5 \pm 0.14$ & $2.09 \pm 0.11$ & $4.01 \pm 0.22$ & $1.98 \pm 0.11$ & $1.97 \pm 0.11$ \\
\hline Total nitrogen $\left(\mathrm{g} \cdot \mathrm{kg}^{-1}\right)$ & $1.5 \pm 0.1$ & $1.4 \pm 0.1$ & $2.0 \pm 0.2$ & $0.8 \pm 0.1$ & $1.3 \pm 0.1$ \\
\hline Phosphorus $\left(\mathrm{g} \cdot \mathrm{kg}^{-1}\right)$ & $1.13 \pm 0.15$ & $0.77 \pm 0.10$ & $0.88 \pm 0.11$ & $0.77 \pm 0.10$ & $0.544 \pm 0.07$ \\
\hline Potassium $\left(\mathrm{mg} \cdot \mathrm{kg}^{-1}\right)$ & $1,270 \pm 270$ & $1,180 \pm 250$ & $3,800 \pm 800$ & $510 \pm 110$ & $530 \pm 110$ \\
\hline Calcium (mg $\left.\cdot \mathrm{kg}^{-1}\right)$ & $2,550 \pm 130$ & $1120 \pm 60$ & $1,790 \pm 90$ & $740 \pm 40$ & $1,020 \pm 50$ \\
\hline Magnesium $\left(\mathrm{mg} \cdot \mathrm{kg}^{-1}\right)$ & $740 \pm 40$ & $1,230 \pm 60$ & $4,840 \pm 240$ & $276 \pm 14$ & $660 \pm 30$ \\
\hline pH (KCl) & $5.20 \pm 0.10$ & $5.50 \pm 0.10$ & $5.50 \pm 0.10$ & $4.10 \pm 0.10$ & $4.50 \pm 0.10$ \\
\hline
\end{tabular}

Table 2 Content of mineral substances in different soil types. 

Stands Vitality in Different Forest Growing Conditions

Table 3 Content of mineral substances in different birch biomass fractions depending on soil type.

\begin{tabular}{|c|c|c|c|c|}
\hline \multirow{2}{*}{ Forest type/soil type } & \multirow{2}{*}{ Mineral nutrient } & \multicolumn{3}{|c|}{ Content of mineral nutrient } \\
\hline & & Foliage & Wood unbarked & Roots \\
\hline \multirow{5}{*}{ Aegopodiosa/ASG } & Total nitrogen $\left(\mathrm{g} \cdot \mathrm{kg}^{-1}\right)$ & 31.4 & 5.9 & 1.3 \\
\hline & Total phosphorus (\%) & 0.744 & 0.08 & 0.124 \\
\hline & Potassium (\%) & 0.299 & 0.061 & 0.150 \\
\hline & Calcium (\%) & 0.660 & 0.488 & 0.688 \\
\hline & Magnesium (\%) & 0.399 & 0.088 & 0.083 \\
\hline \multirow{5}{*}{ Oxalidosa/SP } & Total nitrogen $\left(\mathrm{g} \cdot \mathrm{kg}^{-1}\right)$ & 28.6 & 5.4 & 1.1 \\
\hline & Total phosphorus (\%) & 0.60 & 0.28 & 0.03 \\
\hline & Potassium (\%) & 0.32 & 0.17 & 0.07 \\
\hline & Calcium (\%) & 0.40 & 0.83 & 0.47 \\
\hline & Magnesium (\%) & 0.24 & 0.13 & 0.088 \\
\hline \multirow{5}{*}{ Hylocomiosa/TSC } & Total nitrogen $\left(\mathrm{g} \cdot \mathrm{kg}^{-1}\right)$ & 35.2 & 6.1 & 1.8 \\
\hline & Total phosphorus (\%) & 0.405 & 0.066 & 0.243 \\
\hline & Potassium (\%) & 0.375 & 0.337 & 0.211 \\
\hline & Calcium $(\%)$ & 0.743 & 0.672 & 0.567 \\
\hline & Magnesium (\%) & 0.450 & 0.074 & 0.141 \\
\hline \multirow{5}{*}{ Cladinoso-callunosa/TP $\mathrm{TP}_{1}$} & Total nitrogen $\left(\mathrm{g} \cdot \mathrm{kg}^{-1}\right)$ & 24.8 & 4.6 & 0.75 \\
\hline & Phosphorus (\%) & 0.41 & 0.194 & 0.106 \\
\hline & Potassium (\%) & 0.173 & 0.151 & 0.107 \\
\hline & Calcium (\%) & 0.290 & 0.116 & 0.049 \\
\hline & Magnesium (\%) & 0.303 & 0.039 & 0.031 \\
\hline \multirow{5}{*}{ Myrtillosa/ $/ \mathrm{TP}_{2}$} & Total nitrogen $\left(\mathrm{g} \cdot \mathrm{kg}^{-1}\right)$ & 25.3 & 5.2 & 1.0 \\
\hline & Total phosphorus (\%) & 0.499 & 0.061 & 0.104 \\
\hline & Potassium $(\%)$ & 0.271 & 0.053 & 0.107 \\
\hline & Calcium (\%) & 0.541 & 0.277 & 0.238 \\
\hline & Magnesium (\%) & 0.027 & 0.011 & 0.006 \\
\hline
\end{tabular}

Where, $d_{v}$-diameter of the stand's mean tree, $\mathrm{cm}$.

$$
G=g_{v} \cdot N
$$

Where,

$G$ - stand basal area, $\mathrm{m}^{2}$.

The stock volume is calculated after I. Liepa's a formula [33]:

$$
\mathrm{V}=\psi \cdot \mathrm{h}^{\alpha} \cdot \mathrm{dv} \mathrm{v}^{\beta \cdot \operatorname{lgh}+\varphi}
$$

Where,

$V$ —stem volume overbark, $\mathrm{m}^{3}$;

$L$ - stem length, m;

$D$ - stem diameter overbark, cm;

$\psi, \alpha, \beta, \varphi$-empirically established coefficients (Table 4).

I. Liepa's formula is applied to the young birch stands of the height $\leq 9 \mathrm{~m}$ :

$$
M=k \cdot G \bullet(h+4) \text {, }
$$

Where,

$M$ - stock volume of the stand, $\mathrm{m}^{3} \cdot \mathrm{ha}^{-1}$; $k$-coefficient for the respective tree species (for birch 0.38);

$G$ - stand basal area, $\mathrm{m}^{2} \cdot \mathrm{ha}^{-1}$;

$h$-mean height, $\mathrm{m}$.

To judge of the vitality of birch stands, the impact of entomofauna is evaluated for each sample plot.

Between 10.09 and 15.09, 2012, 100 leaves, taking one leaf from each tree, were collected from four birch stands in different growing conditions (soil/forest type) in different localities (community/locality): ASG/Aegopodiosa (Iecava/Skujenieki); SP/Oxalidosa (Kandava/Straumes);

TSC/Hylocomiosa (Tukums/Vāne); $\mathrm{TP}_{1} /$ Cladinoso-callunosa (Ādaži/Garkalne); $\mathrm{TP}_{2} /$ Myrtillosa (Salaspils). Besides, the distance between 100 trees was determined. In each sample plot the trees for collecting leaf samples were chosen randomly, on average in $1 / 50$ of the sample plot area. 
Table 4 Values of empirical coefficients for calculating stem volume.

\begin{tabular}{lllll}
\hline Tree species & $\psi$ & $\alpha$ & $\beta$ & $\varphi$ \\
\hline Betula pendula Roth & $0.9090 \cdot 10^{-4}$ & 0.71677 & 0.16692 & 1.75701 \\
\hline
\end{tabular}

The collected leaves, evenly spread were dried for 2-3 days. Later, the leaf length was measured by using squared tracing paper with the proportion (in \%) of pest-damaged projection of the leaf surface determined following the type of damage (boreholes, galls, chewing, sucking, skeletonized leaves, unidentified damage).

The Microsoft Excel software was used for mathematically treating the field data with the SPSS for Windows used for statistical analysis.

\section{Results and Discussion}

The field data show the growth of birch to depend strongly on the content of mineral nutrients in soil. As seen from the mean dimensions of even-age stands (10 yrs.) of the experimental plots in forest types Oxalidosa (Kandava/Straumes) and Myrtullosa (Salaspils), there is a significant difference between the soil mineral nutrient content in the respective sites (Tables 1 and 2). These differences may partly be explained by the way the stands were established: in one case artificial (Kandava/Straumes), in other - natural regeneration (Salaspils) and by the soil mineral nutrients abundance. Still, when the authors compare the content of mineral nutrients in similar soil types, these differences are not significant. The even-age birch stands of the experimental plots in Aegopodiosa forest type (Iecava/Skujenieki) and Hylocomiosa (Tukums/Vāne) too differ regarding the content of soil mineral nutrients (Table 2) with differing mean parameters for the respective stands as a result (Table 1). A similar dependence between the soil mineral nutrient content, the $\mathrm{DBH}$ and tree height is observed in other experimental plots too. Most unsuitable for birch are typical podzol soils with sand as a parent rock (forest types Cladinoso-callunosa, Myrtillosa): the mean height and the DBH for 9-year and 10-year stands are only 2.5-3.9 $\mathrm{m}$ and $1.2 \mathrm{~cm}$ and $2.5 \mathrm{~cm}$, respectively (Table 1 ).

In lean soils the biomass of mean tree is also considerably below that in rich soils (Table 3 ). As seen from the field data, the completely dry biomass (in \%) for birches on suitable soils (ASG, TSC and SP) divides between fractions as follows: stem wood $51.8 \%-59.5 \%$; branch wood 9.8\%-12.4\%; roots $25 \%-30 \%$; foliage $5.7 \%-6.8 \%$.

For birches in lean sandy soils $\left(\mathrm{TP}_{1}\right.$ and $\left.\mathrm{TP}_{2}\right)$ in forest types Cladinoso-callunosa and Myrtillosa the stem biomass makes on average $32.3 \%-41.8 \%$, followed by that of roots $(26.8 \%-27.4 \%)$, branch wood (18.2\%-24.2\%), and foliage (13.2\%-16.1\%) (Table 5). It convincingly demonstrates that in poor growing conditions birch consumes more energy for developing roots and increasing the total leaf surface area, thus providing more nutrients for growth. As indicated in the literature, it is the stand density that determines the crown size and accordingly the leaf surface: the higher the stand density, the smaller is the total leaf surface [9].

As it follows from the results of this study, birch as a species is sensitive to the availability of mineral nutrients in soil, and it is the soil fertility that determines the productivity of birch stands. The results of the given study agree with those done in other countries [4, 5, 18, 34-40].

In spring, the moisture content in birch foliage is as high as $72 \%$ with the average content of dry matter $62 \%$ in summer $(59.2 \%-64.1 \%$ in the given case) [41]. In freshly cut birch wood the moisture content was within the range of $45.2 \%-48.3 \%$ of absolutely dry matter (DM); in calculations the authors used the average index $47 \%$ of the DM.

As seen from the field data, the amount of above-ground biomass in 1 ha of a birch plantation 
Table 5 Absolutely dry birch above-ground and root biomass.

\begin{tabular}{|c|c|c|c|c|c|}
\hline \multirow[b]{2}{*}{ Biomass fraction } & \multicolumn{5}{|c|}{ Forest type/soil type } \\
\hline & Aegopodiosa/ASG & Oxalidosa/SP & Hylocomiosa/TSC & $\begin{array}{l}\text { Cladinoso-cal- } \\
\text { lunosa } / \mathrm{TP}_{1}\end{array}$ & Myrtillosa $/ \mathrm{TP}_{2}$ \\
\hline Wood unbarked $\left(\mathrm{t} \cdot \mathrm{ha}^{-1}\right)$ & 83.8 & 10.6 & 48.2 & 1.0 & 3.5 \\
\hline Branch wood $\left(t \cdot h^{-1}\right)$ & 13.7 & 2.5 & 8.4 & 0.7 & 1.5 \\
\hline Foliage $\left(\mathrm{t} \cdot \mathrm{ha}^{-1}\right)$ & 8.0 & 1.2 & 5.6 & 0.5 & 1.1 \\
\hline Total above-ground biomass $\left(\mathrm{t} \cdot \mathrm{ha}^{-1}\right)$ & 105.5 & 14.3 & 62.2 & 2.2 & 6.1 \\
\hline Root biomass $\left(\mathrm{t} \cdot \mathrm{ha}^{-1}\right)$ & 35.3 & 6.14 & 21.1 & 0.8 & 2.2 \\
\hline Total tree biomass $\left(\mathrm{t} \cdot \mathrm{ha}^{-1}\right)$ & 140.8 & 20.44 & 83.3 & 3.0 & 8.3 \\
\hline
\end{tabular}

accounts for $70 \%-75 \%$ of the DM for the whole plantation, with this index $73 \%-74 \%$ in naturally regenerated stands (Table 5).

In this study evaluated was also the mineral nutrient sufficiency for young birch stands in different soils. Nitrogen as an essential component of amino acids and albumins, where the nitrogen makes $16 \%-18 \%$ of the albumin mass, is one of the major nutrients the plants need [42]. According to the field data, the nitrogen content in different soils, where birch is cultivated (ASG, SP and TSC), was $1.44 \mathrm{~g} \cdot \mathrm{kg}^{-1}$ and 2.0 $\mathrm{g} \cdot \mathrm{kg}^{-1}$, which is sufficient for excellent growth. The nitrogen content in typicalpodzol soils $\left(\mathrm{TP}_{1}\right.$ and $\left.\mathrm{TP}_{2}\right)$ is considerably less, $0.8-1.3 \mathrm{~g} \cdot \mathrm{kg}^{-1}$, respectively, with stunted growth of birch as a result (Table 2, Fig. 1).

Phosphorus, as no less important element for plant growth, plays a key role in albumin synthesis, metabolism and energy exchange, photosynthesis, and plant respiration.

The field data of this study show the phosphorus content in soil to correlate with its content in foliage, except for the Myrtillosa $\left(\mathrm{TP}_{2}\right)$ stand (for which additional research is required). Fig. 2 illustrates the phosphorus content in different birch biomass fractions depending on soil type.

Potassium, absorbed by plants, is essential for photosynthesis. It markedly stimulates plant growth, stepping up the dispersion of protoplasm colloids, increasing their hydration, and accordingly enhancing water-retaining forces in cells [42]. Fig. 3 shows the potassium content in different birch biomass fractions depending on soil type.

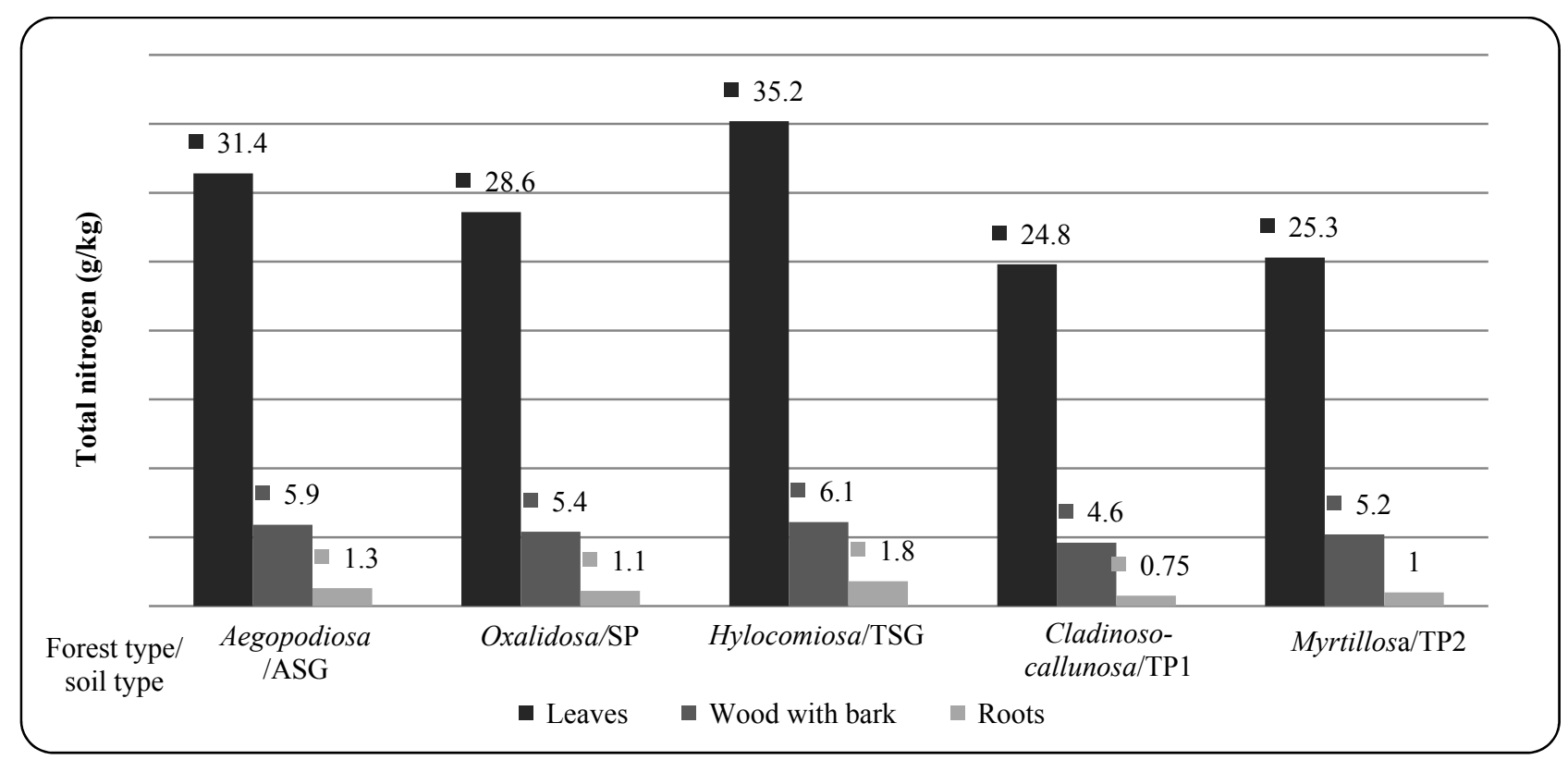

Fig. 1 Total nitrogen content in different birch biomass fractions depending on soil type. 


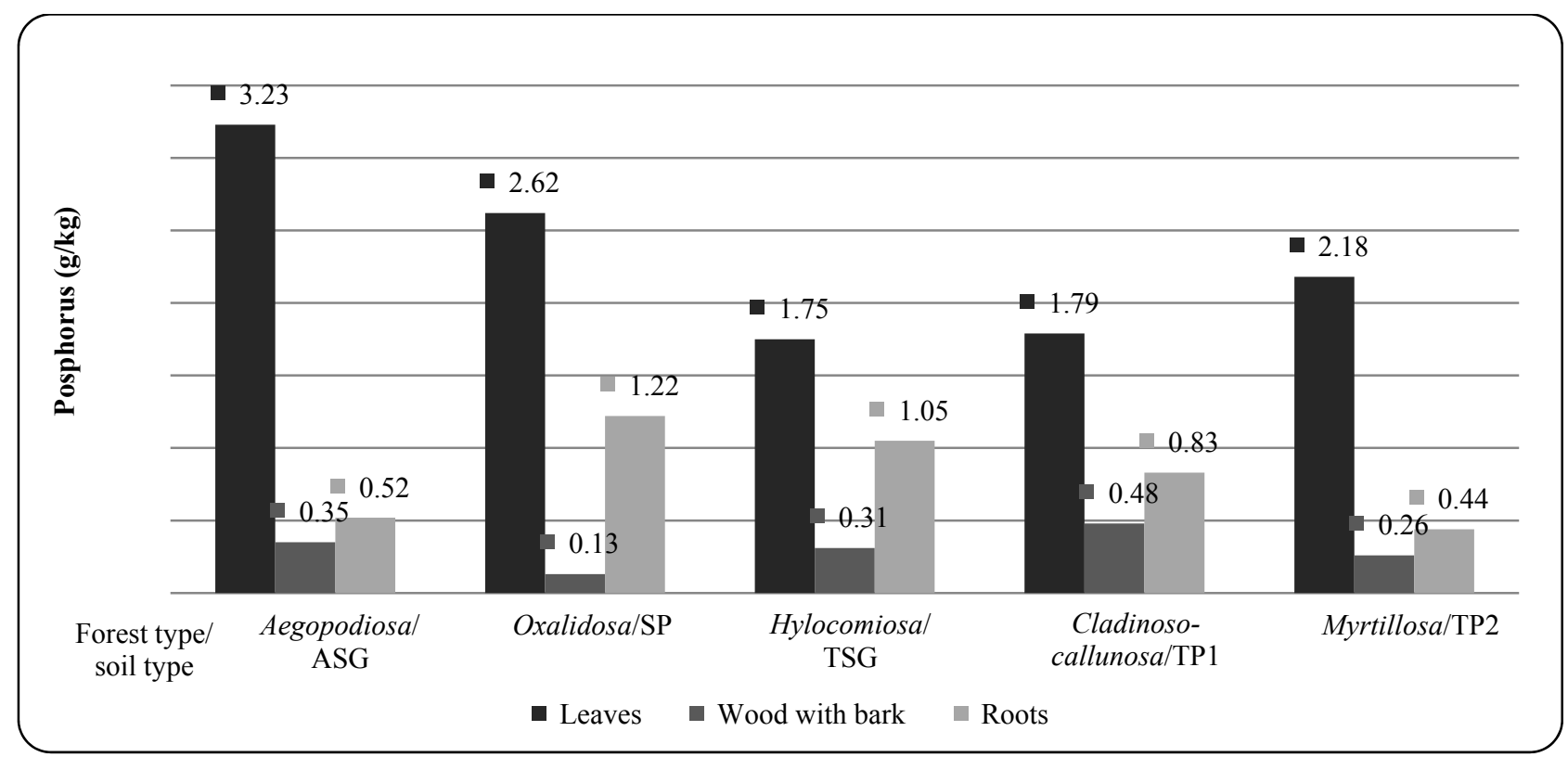

Fig. 2 Phosphorus content in different birch biomass fractions depending on soil type.

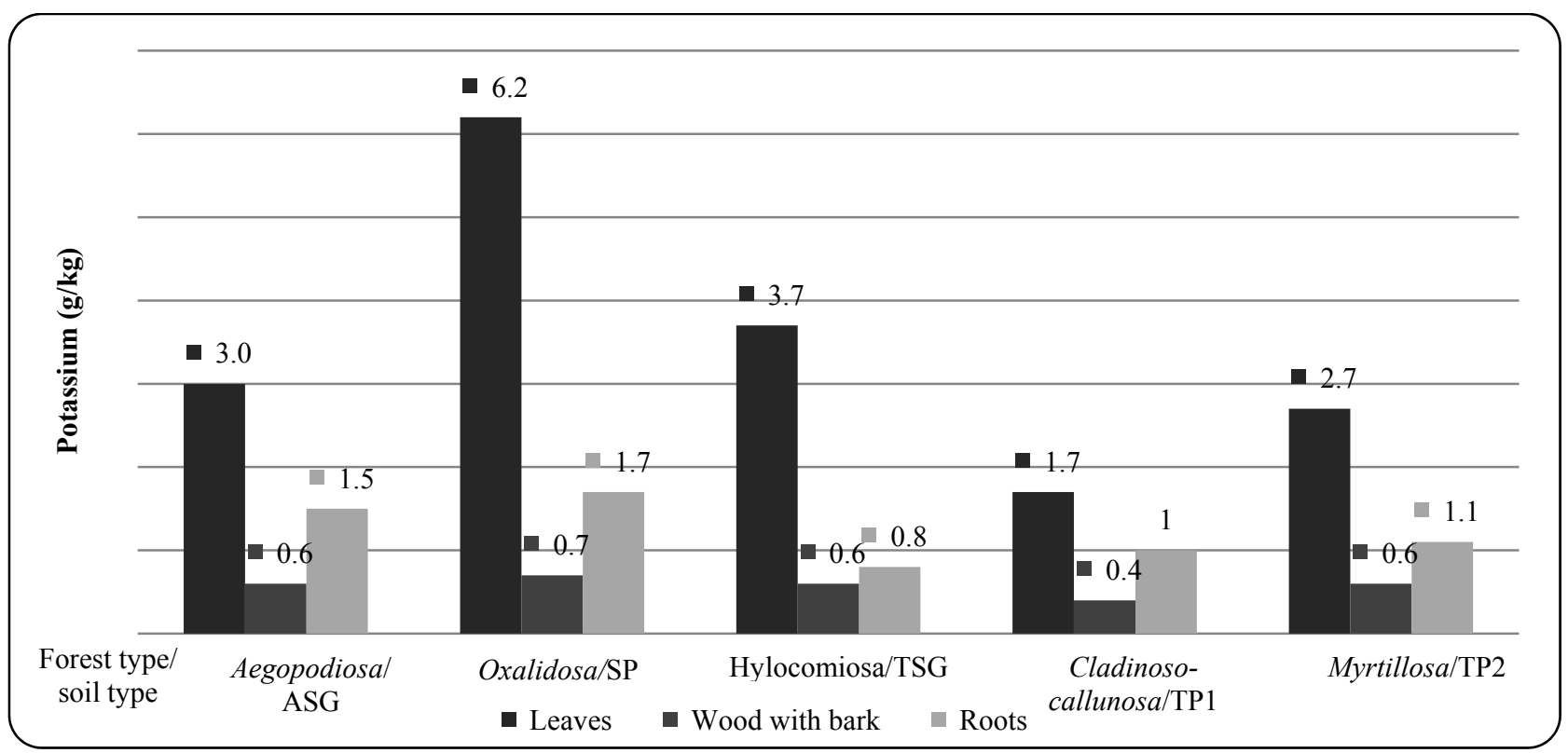

Fig. 3 Potassium content in different birch biomass fractions depending on soil type.

Calcium, present in every plant cell, structure and organelle is indispensable for stabilizing plant physiological functions, and those of the root system in particular [42]. According to the data of the given study, the calcium content in different biomass fractions for birches in lean soils $\left(\mathrm{TP}_{1}\right.$ and $\left.\mathrm{TP}_{2}\right)$ is considerably below that in fertile soils (ASG, SP and TSC) (Fig. 4).

Magnesium, as one of the chlorophyll components, is vital for plant growth [42]. As the data of this study indicate, the growing conditions for birch determine the magnesium content in all biomass fractions (Table 2; Fig. 5). In acid light texture soils $\left(\mathrm{TP}_{1}\right.$ and $\left.\mathrm{TP}_{2}\right)$, the plants quite often suffer from magnesium deficiency, which may appear as leaf chlorosis.

Nutrient cycling is appreciable in rich soils (ASG, TSC and SP), where for birch the amount of aboveand below-ground biomass is high, with mineral 


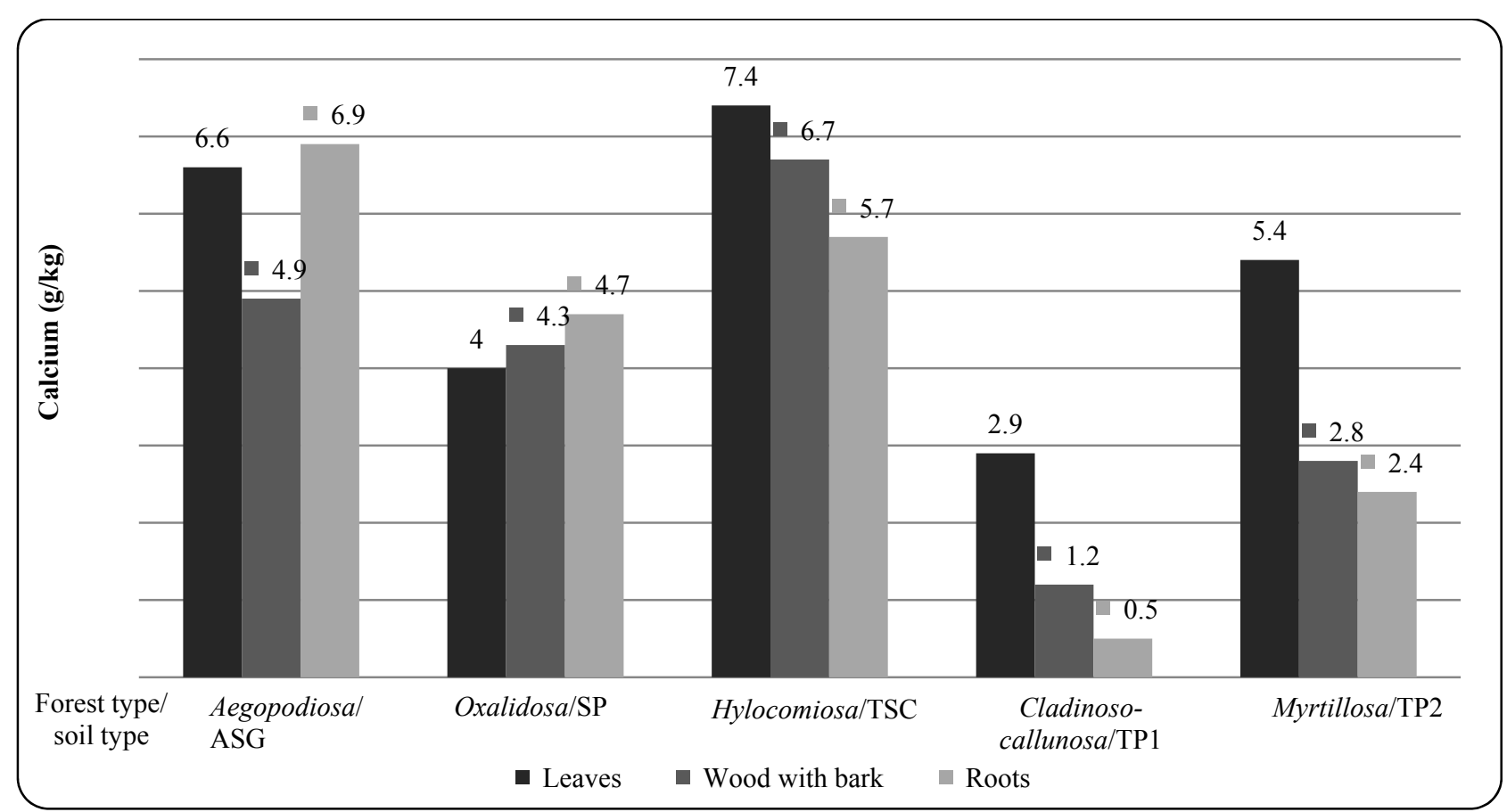

Fig. 4 Calcium content in different birch biomass fractions depending on soil type.

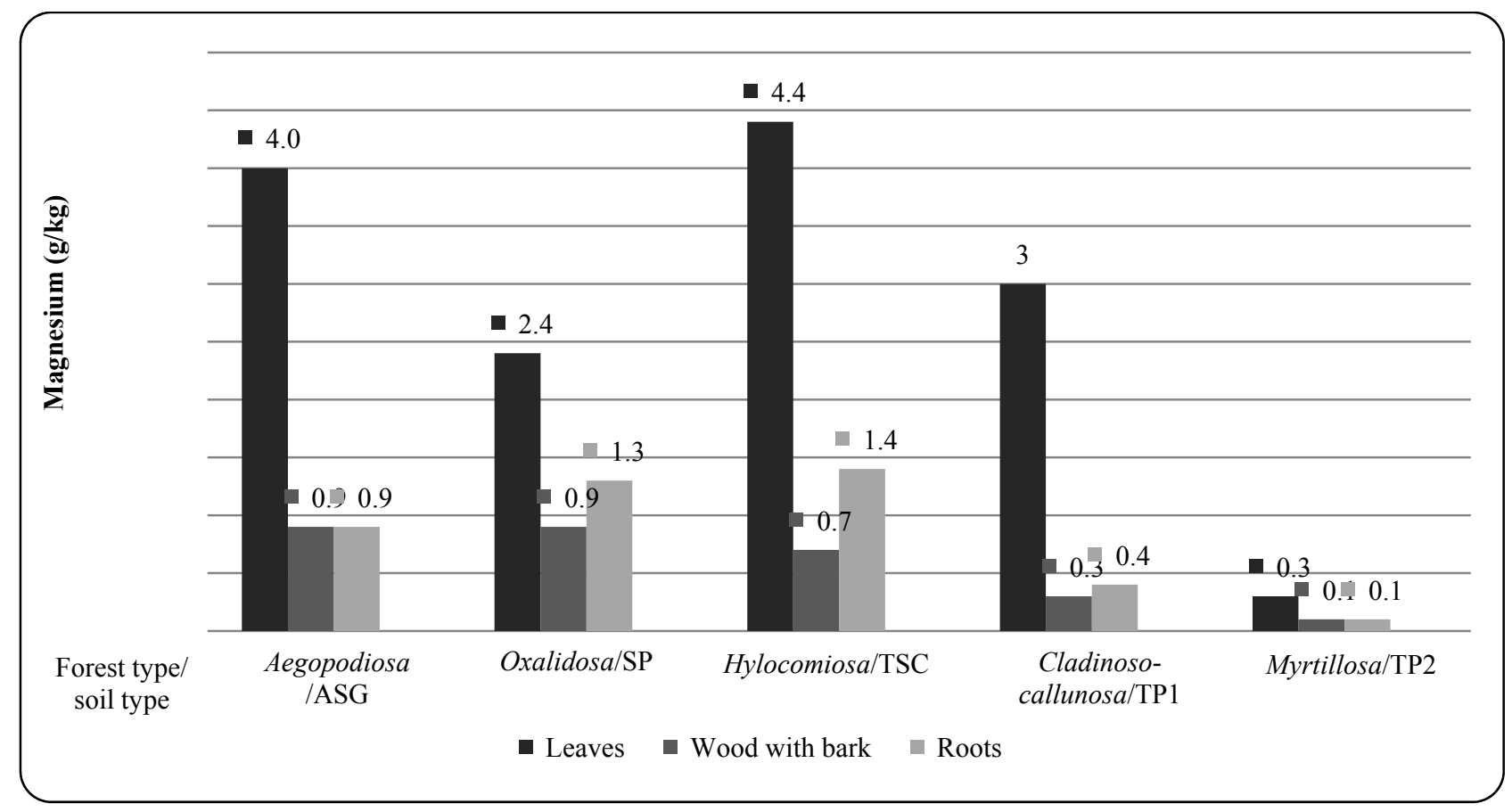

Fig. 5 Magnesium content in different birch biomass fractionss depending on soil type.

reserves supplemented by both leaf and twig litter and decaying roots. In barren soils $\left(\mathrm{TP}_{1}\right.$ and $\left.\mathrm{TP}_{2}\right)$, the reserves of mineral substances are inadequate, which adversely affect the performance of birch.

According to the data of Table 5, out of all sample plots studied the soil mineral nutrient content is highest for the Hylocomiosa/TSC (Tukums/Vāne) site, while the performance of birch is below that at the Aegopodiosa/ASG (Iecava/Skujenieki) site, where the stand is of the same age. These differences are 


\section{Stands Vitality in Different Forest Growing Conditions}

attributable to soil conditions: at the Hylocomiosa/TSC (Tukums/Vāne) site the parent rock is heavy clay, at Aegopodiosa/ASC (Iecava/Skujenieki) — average sandy clay. It agrees with the conclusions of K. Liepinšs, that in compacted heavy soils birch growth is retarded [39].

The findings of the given study agree with the conclusions of Finnish and Swedish researchers, that birch as a species is sensitive to the availability of soil mineral nutrients, which is decisive for birch productivity $[7,40,43]$.

The growth of young birch stands closely correlates with the mineral nutrient content in the soil $(\mathrm{P}, \mathrm{N}, \mathrm{K}$, $\mathrm{Ca}$ and $\mathrm{Mg})$ : in barren typical podzol soils $\left(\mathrm{TP}_{1}, \mathrm{TP}_{2}\right)$ the mineral substance content is no more than $20 \%-48 \%$ of that in nutrient-rich soils (ASG, TSC and SP) (Table 2).

The content of other mineral substances, in plant physiology known as microelements, varied in different biomass fractions from different experimental sites over quite a wide range. However, studying the content of these elements in different birch biomass fractions depending on growing conditions was outside the scope of this study. According to a study done in Finland [7], there is no correlation between the soil conditions and the microelement content in different birch biomass fractions (foliage in particular).

It appears, that the growth of birch primarily depends on such factors as the availability of $\mathrm{N}, \mathrm{P}$ and $\mathrm{K}$ in the soil, soil consistence, microclimate, light, precipitation, etc., the more so because in lean sandy soils (Cladinoso-callunosa and Myrtillosa/TP) the growth of birch is stunted quite considerably (Table $1)$.

As it follows from the field data, in young birch stands the take-up of mineral nutrients over a period of 10-15 years for developing the above-ground biomass makes a fairly small proportion of the total. In fertile soils (ASG, TSC and SP) the birch needs for mineral nutrients at the respective stage of growth determines the amount taken up by it.

When analysing the leaves collected in sample plots for determining the type and amount of pest damage, there were considerable differences between different experimental sites, with the highest degree of damage in the Hylocomiosa forest type on the heavy clay (Tukums/Vāne) and Cladinoso-callunose forest type (Ādaži/Garkalne) sites (Table 1). In the former case, totally $63 \%$ of birch leaves showed the signs of damage - an indication of potential outburst of secondary pests in the summer to come (Fig. 6). However, it deserves mention, that regardless of similarity between the amount of chewed, skeletonized and otherwise damaged leaves in the two sites, there are significant differences regarding other types of damage (Fig. 7). It suggests, that locally there may exist a variety of so far unknown factors (microclimate, for instance), restricting the pest activity. The ways of dividing up the feeding niches between different regions of pest multiplication may serve as a means for reducing interspecies competition. Still, the state of birch foliage health is comparatively better in the sites of Aegopodiosa forest type (Iecava/Skujenieki) and Oxalidosa forest type (Kandava/Straumes) (Fig. 6).

Correlation coefficient, $r=-0.89$, was obtained by establishing Pirson's correlation for the mean distances between trees and the mean total amount of damage per leaf in each sample plot. It is found, that with the distance between trees getting smaller, the total amount of leaf damage (pest activity) is increasing, conceivably because of winds slowed down in denser stands. As to the types of damage, the most common ones are skeletonized leaves, as well as those damaged by gnawing and sucking insects (Fig. 7). It indicates that in Latvia, the pests with these feeding habits are on the increase.

The proportional relationship is reverse for the total amount of leaf damage and the leaf size. In this case the Pirson's correlation (correlation coefficient $r=$ -0.99 ) point to a markedly negative correlation for the 


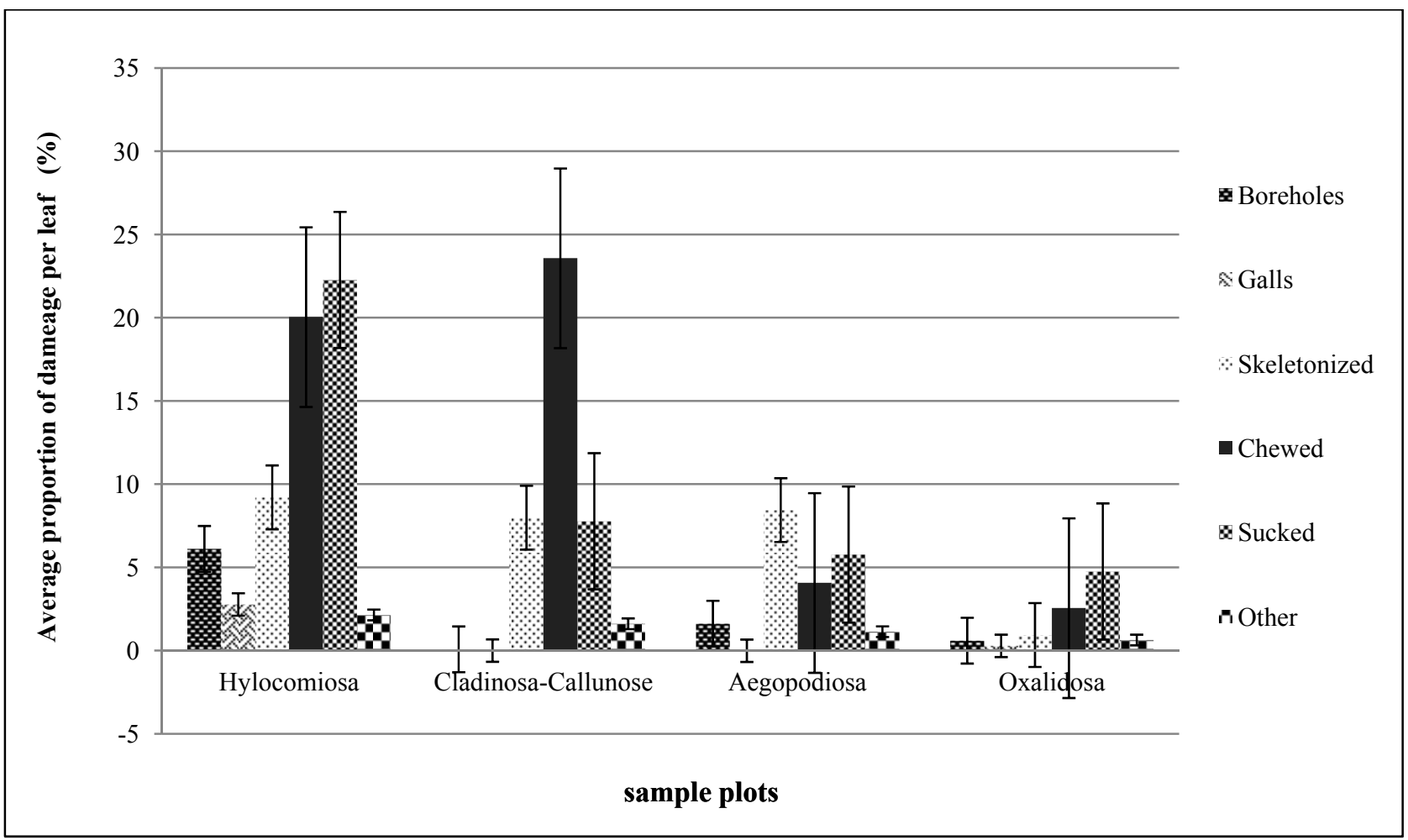

Fig. 6 Distribution of different types of birch leaf damages between sample plots.
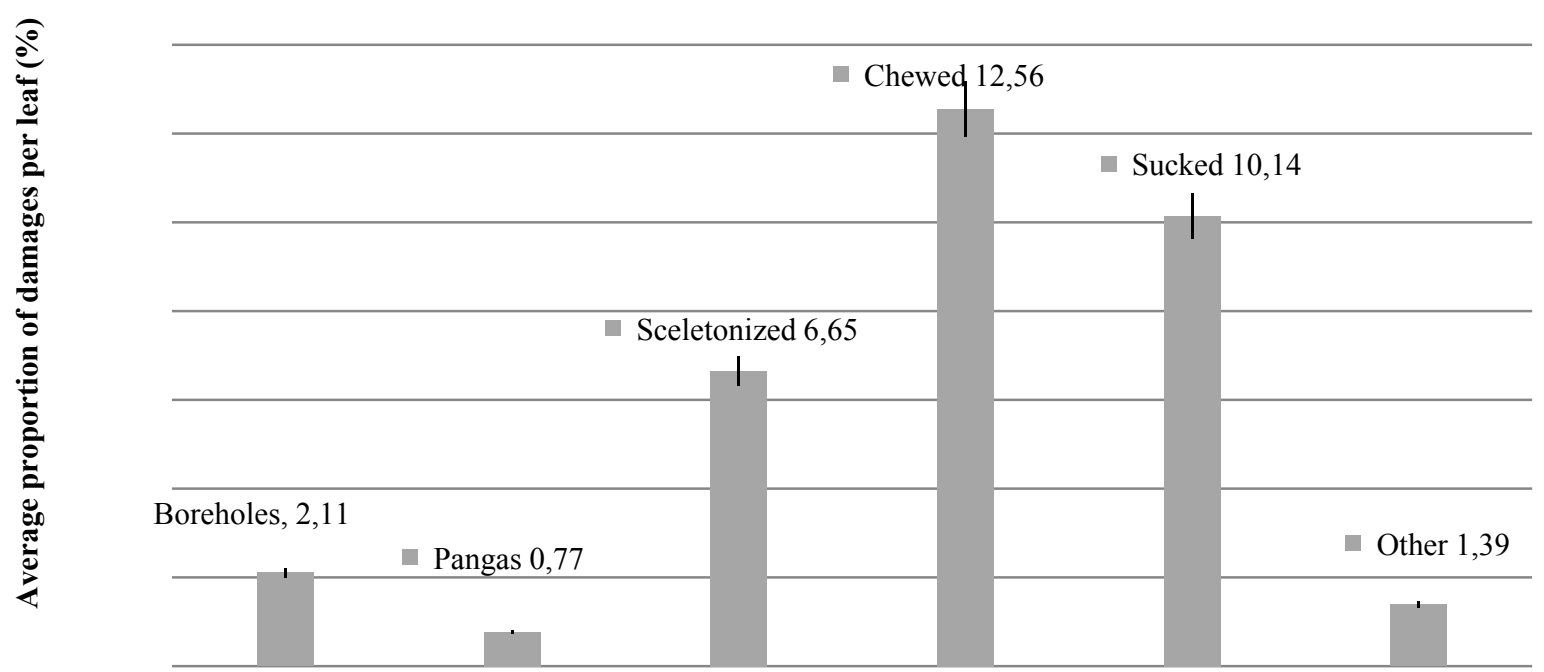

Damages

Fig. 7 Total mean amount of leaf damages per leaf in birch stands.

variations in the amount of damage. These are comparatively smaller leaves, which show the signs of damage. Normally, leaf size is an indirect indicator of the growing conditions and soil nutrient sufficiency (the more nutrients, the better condition of foliage). On the other hand, pest activities may affect the leaf size, since the leaves get less nutrients because of it.

While working on the given project, it was 
concluded, that at present no reliable evaluation of the impact of individual mineral nutrient availability on the growth and vitality of young birch stands in agricultural and forest soils is possible because of the limited number of sample plots and measurement replications. A similar study ought to be done over a longer time span with a higher number of replications.

It was also concluded, that there is a need for further research in order to evaluate the impact of individual mineral nutrients, and microelements in particular, on the vitality of birch, cultivated in soils with controlled mineral nutrient content, as recommended by research on plant physiology.

\section{Conclusions}

The growth of young birch stands closely correlates with the availability of soil mineral nutrients needed by plants $(\mathrm{P}, \mathrm{N}, \mathrm{K}, \mathrm{Ca}$ and $\mathrm{Mg})$ : in barren forest types Cladinosa-callunose and Myrtullosa on typicpodzol soils the mineral nutrient content in no less than $20 \%-48 \%$ of that in more fertile forest types-Hylocomiosa, Oxalidosa and Aegopodiosa on the soils (ASG, TSC and SP).

In forest types Hylocomiosa, Oxalidosa and Aegopodiosa on fertile soils (ASG, VKt and PVv) the total amount of biomass produced by young birch stands divides into fractions as follows: stem wood $51.8 \%-59.5 \%$; branch wood $9.8 \%-12.4 \%$, foliage 5.7\%-6.8\%; stump wood and roots 25\%-30\%.

In forest types Myrtillosa and Cladinoso-callunose on barren soils $\left(\mathrm{TP}_{1}\right.$ and $\left.\mathrm{TP}_{2}\right)$ the stem wood make $32.3 \%-41.8 \%$, branch wood $18.2 \%-24.2 \%$, foliage $13.2 \%-16.1 \%$, and roots $26.8 \%-27.4 \%$ of the total biomass.

The analyses of pest damages in young stands of birch confirm a hypothesis, that the degree of pest damage depends on stand vitality as described by the site index for the respective site.

\section{Acknowledgement}

The authors acknowledge the support for the given study of the ESF project "Setting up a research team for studying interaction between nanoparticles and biological objects".

(No. 2013/0029/1DP/1.1.1.2.0/13/APIA/VIAA/029).

\section{References}

[1] Central Statistical Bureau of Latvia. 2010. "Forestry-key Indicators." Assessed March, 2015. http://www.csb.gov.lv/en/statistikas-temas/forestry-key-i ndicators-30729.html.

[2] Ovington, J. D. 1965. "Organic Production, Turnover and Mineral Cycling in Woodlands.” Biological Reviews 40 (3): 295-336.

[3] Marchner, H., Kirkby, E. A., and Cakmak, I. 1996. "Effect of Mineral Nutritional Status on Shoot-root Partitioning of Photoassimilates and Cycling of Mineral Nutrients." Journal of Experimental Botany 47: 1255-1268.

[4] Karlsson, A., Albrekson, A., and Sonoson, J. 1997. "Site Index and Productivity of Artifically Regenerated Betula Pendula and Betulapubescens Stand on Former Farmland of Southern and Central Sweden." Scandinavian Journal of Forest Research 12: 256-263.

[5] Valkonen, S., and Valsta, L. 2001. "Productivity and Economics of Mixed Two-storied Spruce and Birch Stands in Southern Finland Simulated with Empirical Models." Forest Ecology and Management 140: 133-149.

[6] Brandtberg, P. O., Bengtsson, J., and Lundkvist, H. 2004. "Distributions of the Capacity to Take up Nutrients by Betula Spp. and Piceaabies in Mixed Stands." Forest Ecology and Management 198: 193-208.

[7] Saramaki, J., and Hytonen, J. 2004. "Nutritional Status and Development of Mixed Plantations of Siver Birch (Betula Pendula Roth) and Downy Birch (BetulapubescensEhrh.) on Former Agricultural Soils." Baltic Forestry 10 (1): 2-11.

[8] Rasmussen, C., Southard, R. J., and Norwath, W. R. 2006 "Mineral Control of Carbon Mineralization in a Range of Temperate Conifer Forest Soils." Global Change Biology 12: 834-847.

[9] Uri, V., Lohmus, K., Ostonen, I., Tullus, H., Lastik, R., and Vildo, M. 2007. "Biomass Production, Foliar and Root Characteristics and Nutrient Accumulation in Young Silver Birch (Betula pendula Roth.) Stand Growing on Abandoned Agricultural Land." Eur. J. Forest Res. 126 (4): 495-506.

[10] Walle, I. V., Camp, N. V., Casteele, L., Verheyen, K., and Lemeur, R. 2007. "Short-rotation Forestry of Birch, Maple, Poplar and Willow in Flanders (Belgium) II. Energy Production and $\mathrm{CO}_{2}$ Emission Reduction Potential." Biomass and Bioenergy 31: 276-283. 
[11] Nabuurs, G. J., Hengeveld, G. M., Werf, D. C., and Heidema, A. H. 2009. "European Forest Carbon Balance Assessed with Inventory Based Methods-An Introduction to a Special Section." Forest Ecology and Management 260: 239-240.

[12] Kund, M., Vares, A., Sims, A., Tullus, H., and Uri, V. 2010. "Early Growth and Development of Silver Birch (Betula pendula)." Eur. J. Forest Res. 129: 679-688.

[13] Rosenvald, K., Ostonen, I., Truu, M., Truu, J., Uri, V., Vares, A., and Lohmus, K. 2011. "Fine Root Rhizosphere and Morphological Adaptations to Site Conditions in Interaction with Tree Mineral Nutrition in Young Silver Birch (Betula pendula Roth.) Stands.” Eur. J. Forest Res. 130 (6): 1055-1066.

[14] Chertov O. G., and Komarov A. S. 1997. "SOMM: A Model of Soil Organic Matter Dynamics." Ecological Modelling 94 (2-3): 177-190.

[15] Chertov, O. G., Komarov, A. S., Nadporozhskaya, M., Bykhovets, S. S., and Zudin, S. L. 2001. "ROMUL-A Model of Forest Soil Organic Matter Dynamics as a Substantial Tool for Forest Ecosystem Modelling." Ecological Modelling 138: 289-308.

[16] Chertov, O., Komarov, A., Andrienko, N., and Gatalsky, P. 2002. "Integrating Forest Simulation Models and Spatial-temporal Interactive Visualisation for Decision Making at Landscape Level.” Ecological Modelling 148 (1): 47-65.

[17] Kolström M. 1998. "Ecological Simulation Model for Studying Diversity of Stand Structure in Boreal Forests." Ecol. Model 111: 17-36.

[18] Varik, M., Aosaar, J., Ostonen, I., Lohmus, K., and Uri, V. 2013. "Carbon and Nitrogen Accumulation in Belowground Tree Biomass in a Chronosequence of Silver Birch Stands." Forest Ecology and Management 302: $62-70$

[19] Ильинский, А. И., and иТропин, И. В. 1965. Надзор, Учет И Прогноз Массовых Размножений Хвое-и Листогрызущих Насекомых. Леснаяпромышленность.

[20] Allard, G. B., Fortuna, S., Lee, S. S., Novotny, J., Baldini, A., and Courtinho, T. 2003. "Global Information on Outbreaks and Impact of Major Forest Insect Pests and Diseases." Presented at 7th World Forestry Congress Paper. Canada.

[21] Rupais, A. 1999. Guidelines of Tree and Shrubs Pests in Gardens and Parks. Riga: State Plant Protection Service.

[22] Dwyer, G., Dushoff, J., and Yee, S. H. 2004. "The Combined Effects of Pathogens and Predators on Insect Outbreaks." Nature 430: 341-345.

[23] Cory, J. S., and Hoover, K. 2006. "Plant-mediated Effects in Insect-pathogen Interactions." Trends in Ecology \& Evolution 21: 278-286.
[24] Kurkela, T., Aalto, T., Varama, M., and Jalkanen, R. 2005. "Defoliation by the Common Pine Sawfly (Diprionpini) and Subsequent Growth Reduction in Scots Pine: a Retrospective Approach." Silva Fennica 39 (4): 467-480.

[25] Lynn, K. A. 2009. User-friendly Methods for Timing Integrated Pest Management Strategies: an Analysis of Degree-day Models and Biological Calendars. Ohio State University: Entomology.

[26] Singh, T. V. K., and Satyanarayana, J. 2009. "Insect Outbreaks and Their Management." Integrated Pest Management Innovation-development Process 1: 331-350.

[27] Kaposts V. and Sacenieks R. 1973. "Nutrition Regime of Birch (Betula Pendula Roth) Stands." Mežsaimniecība Un Mežrūpniecība 5: 12-17.

[28] Daugaviete, M., Liepins, K. and Liepins, J. 2011. "The Growth of Silver Birch (Betula pendula Roth.) in Plantations of Different Density." Mežzinātne 24: 3-16.

[29] Kaposts, V., Daugaviete, M., Liepins, K., and Lazdins, A. 2005. Influence of Soil Agrochemical Properties on the Productivity of Birch (Betula pendula Roth) Stands. Rewiev. Salaspils: LSFRI Silava.

[30] Daugaviete, M., Gaitnieks, T., Klavina, D., and Teliseva, G. 2008. "Carbon Accumulation in the Above-ground and Root Biomass of Pine, Birch and Spruce Cultivated in Agricultural Soils." Mežzinātne 18: 35-52.

[31] Zalitis, P., and Jansons, J. 2013. Typology of Latvia's Forests. Salaspils, LSFRI Silava: Daugavpils University Academic Press "Saule".

[32] Karklins, A. 2008. Guidelines for Soil Diagnosis and Description. Jelgava: LUA.

[33] Liepa, I. 1996. Science about Forest Increment. Jelgava: LUA.

[34] Malkonen, E. 1977. "Annual Primary Production and Nutrient Cycle in Birch Stands." Comm. Inst. For. Fenn. 91 (5): 1-35.

[35] Mälkönen, E., and Saarsalmi, A. 1982. "Hieskoivikon Biomass Atuotosja Ravinteiden Menetys Kokopu Unkorjuussa. Summary: Biomass Production and Nutrient Removal in Whole Tree Harvesting of Birch Stands." Folia Forestalia 534: 32.

[36] Niemistö, P. 1991. "Hieskoiviko Iden Kasvatusti Heys Jaharvennus Mallit Pohjois-Suomen Turvemailla. Summary: Growing Density and Thinning Models for Betula pubescens Stands on Peatlands in Northern Finland." Folia Forestalia 782: 36.

[37] Johansson, T. 1999. "Biomass Equations for Determining Fractions of Pendula and Pubescent Birches Growing on Abandoned Farmland and Some Practical Implications." Biomass and Bioenergy 16 (3): 223-238.

[38] Johansson, T. 2007. "Biomass Production and Allometric 

Stands Vitality in Different Forest Growing Conditions

Above-ground and Below-ground Relations for Young Birch Stands Planted at Four Spacings on Abandoned Farmland." Forestry 80 (1): 41-52.

[39] Liepins, K. 2011. "Growth of Silver Birch (Betula pendula Roth.) in Plantations on Farmlands in Latvia." Mežzinātne 23: 3-14.

[40] Hytönen, J., and Aro, L. 2012. "Biomass and Nutrition of Naturally Regenerated and Coppiced Birch on Cutaway Peatland During 37 Years." Silva Fennica 46 (3): 377-394.
[41] Rippi, M., Osasipov, V., Lempa, K., Haukuoija, K., Koricheva, J., Ossipova, S., and Pihjala, K. 2002. "Seasonal Changes in Birch Leaf Chemistry: Are There Trade-offs between Leaf Growth and Accumulation of Phenolics." Oecologia 130: 380-390.

[42] Rinkis, G., and Ramane, H. 1989. Nutrition of Plants. Riga: Avots.

[43] Hytonen, J. 1996. "Biomass Production and Nutrition of Short Rotation Plantations." Finnish Forest Research Institute Research Papers 586: 61. 